\author{
CEZARY KABAŁA $^{1 *}$, MARCIN ŚWITONIAK ${ }^{2}$, PRZEMYSŁAW CHARZYŃSKI ${ }^{2}$ \\ ${ }^{1}$ Wrocław University of Environmental and Life Sciences, Institute of Soil Science and Environmental Protection \\ Grunwaldzka 53, 50-357 Wroctaw, Poland \\ ${ }^{2}$ Nicolaus Copernicus University, Department of Soil Science and Landscape Management \\ Lwowska 1, 87-100 Toruń, Poland
}

\title{
Correlation between the Polish Soil Classification (2011) and international soil classification system World Reference Base for Soil Resources (2015)
}

\begin{abstract}
The recent editions of the Polish Soil Classification (PSC) have supplied the correlation table with the World Reference Base for Soil Resources (WRB), which is the international soil classification most commonly used by Polish pedologists. However, the latest WRB edition (IUSS Working Group WRB 2015) has introduced significant changes and many of the former correlations became outdated. The current paper presents the closest equivalents of the soil orders, types and subtypes of the recent edition of the PSC (2011) and WRB (IUSS Working Group WRB 2015). The proposals can be used for general correlation of soil units on maps and in databases, and may support Polish soil scientists to establish the most appropriate equivalents for soils under study, as well as make PSC more available for an international society.
\end{abstract}

Keywords: Polish Soils Classification, WRB, equivalents, reference soil groups, soil types

\section{INTRODUCTION}

Pedology appeared in the second half of the $19^{\text {th }}$ century as a branch of modern science. From the very beginning it was very important to develop a system of soil classification combining the scientific and application functions. Several concepts were proposed just in the $19^{\text {th }}$ century, based mainly on the geological or agronomical approaches. The first attempt to soil classification related to climate and vegetation zonality was presented by Dokuchaev in 1879 (Strzemski 1971) and then refined by himself(Dokuchaev 1886) and his successors, mainly Sibircev and Glinka (Strzemski 1971). This so-called "genetic" approach to soil classification has spread in the world during the first decades of the $20^{\text {th }}$ century.

The next milestone in the development of soil classification was a "quantitative" approach, initiated by US Soil Survey Staff in early second half of $20^{\text {th }}$ Century (Soil Survey Staff 1960, Brevik et al. 2016). Numerous studies on soil genesis and classification in the following decades led to an improvement of the quantitative system as the Soil Taxonomy (Soil Survey Staff 2014) and broad international acceptation for its rational quantitative concept. Presently, the Soil Taxonomy is used in over 40 countries (Krasilnikov 2002) as a primary system for naming the soils. However, the modern "American" terminology and breaking the link between soil genesis and classification scheme was unacceptable for many other scientists across the world, which led to the development of independent new system of international soil classification, initially as a Legend to Soil Map of the World and then - the World Reference Base for Soil Resources, WRB (FAO-ISSS-ISRIC, 1998). Although the WRB was originally designed as an umbrella encompassing all the world's soils at rather higher classification level and small cartographic scale ("reference base"), in several countries it has been adopted as a basic soil classification and mapping system, e.g. in Mexico, Norway, Tanzania, and Vietnam (Krasilnikov et al. 2009). Nevertheless, pedologists in many countries still develop the national schemes of soil classifications and use the WRB mainly as a "lingua franca", a tool for correlation of the national soil classification systems.

Numerous studies have been published since the release of the $1^{\text {st }}$ edition of WRB (IUSS Working Group WRB 1998) aiming on the correlation issues. 
An approximated correlation between the Czech, Romanian, Latvian, and Brazilian classifications and WRB were presented by Nemeček et al. (2001), Munteanu and Florea (2002), Karklins (2002), and Palmieri et al. (2003), respectively. Correlation between the Polish soil classification, PSC (1989) and WRB was discussed in the book of Charzyński (2006). Extended comparison of the WRB and a number of national soil classifications was given by Krasilnikov (2002). A Handbook of Soil Terminology, Correlation and Classification by Krasilnikov et al. (2009) provided a correlation with the second edition of WRB. New correlations with the third edition of WRB (IUSS Working Group WRB 2006) was performed e.g. for Romanian (Secu et al. 2008) and Croatian systems (Husnjak et al. 2010). Defective correlation may result from various reasons. Soil taxa may have broader or narrower definitions in national classification than WRB groups and some taxa only partially coincide (Zádorová and Penížek 2011). The correlativity of particular soil unit depends on the level of conformity of the threshold values in its diagnostic criteria. Such limits can vary remarkably in different reference units (Shi et al. 2010). Another difficulty in correlation procedures is associated with the different analytical protocols used for delimitation of diagnostic horizons and features (Reintam and Köster 2006). Some confusion in the correlation may be born from perfunctory consideration of units named similarly or identical, or from the qualitative approach to recognition of diagnostic horizons and features. In the latter case, the "expert knowledge" prevails, and the correlations are indicated without consideration of the differences and similarities between the diagnostics criteria. Sometimes, even the authors themselves admit that their correlation is approximate only (Husnjak et al. 2010). As a result, such correlations provide only the basic interrelationships and are subject to a number of inaccuracies (Charzyński 2006).

An increasing demand for harmonized digital soil information can be observed nowadays. The correlation of national systems with WRB has got a new priority, as it is necessary for the development of European and global databases, giving the opportunity to enrich them with more new data. Interesting approach to it, based on calculations of the taxonomic distances between the selected types of Hungarian soils and related WRB RSGs was presented by Láng et al. (2013).

The recent $5^{\text {th }}$ edition of Polish Soil Classification, PSC5 (2011) contains a table of correlation with WRB and the Soil Taxonomy. The third edition of WRB was released in 2014, with upgrades in 2015 (IUSS Working Group WRB 2015) with a number of significant changes. Many of the existing correlation data require reinterpretation and updating. In fact, most of soil units cannot be simply correlated due to several reasons stated above. In case of PSC5 (2011) the main reasons of uncertainty are: traditional ("genetic") attempt to soil classification, the lack of dichotomic (decision-making) classification key, and differences in diagnostic horizons/materials definitions.

The aim of this study is to indicate the closest correlations between the recent edition of the PSC (2011) and WRB (IUSS Working Group WRB 2015). Given proposal may support Polish soil scientists to establish the most appropriate equivalents for soils under study, as well as make PSC more clear and available for an international society. The proposal is based on a comparison of the definitions of diagnostics and properties required for soil units distinguished in both classification systems (Orders, Types and Subtypes in a case of PSC5 and Reference Soil Groups and qualifiers in the case of WRB).

\section{THE ADAPTATION OF WRB BY POLISH SOIL SCIENTISTS}

The WRB is widely used by Polish authors that was confirmed by conducted queries. More than 100 articles released in years 2011-2015, containing information about the systematic placement of soils, were analyzed in the review (Fig. 1). Four scientific journals were taken into consideration: Soil Science Annual (SSA), Polish Journal of Soil Science (PJSS), Geoderma, and Catena. The first two are the most relevant Polish journals dealing with issues of soil science. In the next two international journals the papers written by Polish authors appear more frequent recently.

In all four journals, soils were classified according to WRB in most of the papers. In the Polish journals (i.e. SSA and PJSS), WRB is commonly used simultaneously with PSC (e.g. Dębska et al. 2012, Gajewski et al. 2015, Glina et al. 2014, Mendyk et al. 2015, Musztyfaga and Kabała 2015, Świtoniak 2015, Zagórski et al. 2015). WRB is the only used soil classification system in most articles published in Geoderma and Catena (e.g. Waroszewski et al. 2013, Szymański et al. 2014, Uzarowicz and Skiba 2011), whereas PSC was rarely used as the only classification (without at least comparison with international systems). Such papers were published mainly in the Polish journals as reviews or discussions on PSC (e.g. Kabała 2014, Marcinek et al. 2014), and only in one paper of Catena (Zgłobicki et al. 2015). In the latter case, names of soils have the wording similar to the WRB. Among another systems, only the Soil Taxonomy and only in 
FIGURE 1. The use of classification systems in the papers focusing on Polish soils (based on papers published in years 2011-2015)

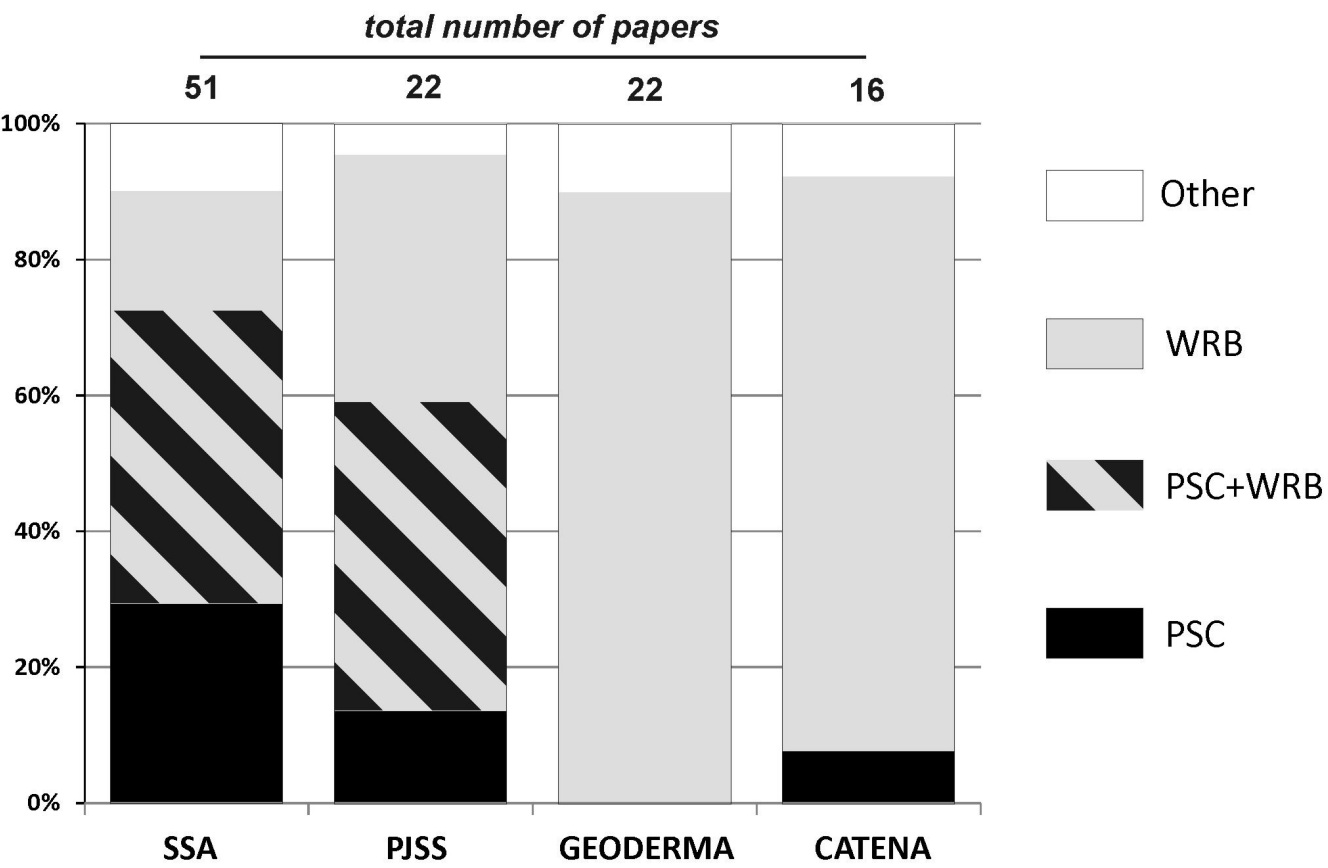

two papers was applied. In one case along with PSC (Józefaciuk and Czachor 2014), and in the second case - along with WRB (Pawlik et al. 2013).

A great importance of WRB was also reflected in pedological monographs recently published in Poland. Although related to soils of Poland, they are often published in English (Charzyński et al. (Eds.) 2013, Świtoniak and Charzyński (Eds.) 2014) or bilingually (Kabała (Ed.) 2015) with the soil names defined according to WRB.

\section{PROPOSED CORRELATIONS OF PARTICULAR SOIL UNITS}

Resent edition of WRB (IUSS Working Group WRB 2015) has introduced a number of significant changes in relation to the previous versions. The proposed correlation table (Table) includes many novel suggestions for soil classification compared with the previous proposals (PSC 2011). The English equivalents for the Polish names of orders, types and subtypes are given after the recent proposal of Świtoniak et al. (2016).

Order 1: Raw mineral soils (gleby inicjalne)

The raw soils order brings together soils at the early (initial) stage of development. WRB has allocated such soils among different RSGs characterized by little or no profile differentiation or with severe limitations to root growth. Raw rocky (gleby inicjalne skaliste) and raw debris soils (gleby inicjalne rumoszowe) can be classified as Leptosols (Table). First type comprises soils with often discontinuous thin organic layer resting directly on the hard or cracked rock, which can be emphasized by the Nudilithic qualifier (Kabala et al. 2013). For subtype of raw rocky rendzinas (rędziny inicjalne skaliste), formed by weathering of carbonate rocks, Calcaric is another vital qualifier. The second type, debris soils (gleby inicjalne rumoszowe), may be apparently deep, but are extremely skeletal, thus Nudilithic qualifier have been replaced with Hyperskeletic one. Raw regosols (gleby inicjalne erozyjne) were formed by strong erosion and truncation of the original soils and the lack of soil horizons (Protic qualifier). Their current properties are strictly related to the features (e.g. texture, reaction) of unconsolidated parent materials. The forth type, raw accumulation soils (gleby inicjalne akumulacyjne) are formed mainly from recent eolian (Protic Arenosols) (Jankowski et al. 2014) or fluvial (Gleyic Fluvisols) deposits. However, initially developed alluvial soils with strong gleyic properties starting near the mineral surface should be classified as Fluvic Gleysols. That RSG was purposely placed in the classification key before Fluvisols to emphasize greater ecological and pedological role of reducing conditions than geomorphological processes.

\section{Order 2: Weakly developed soils (gleby słabo ukształtowane)}

The soils of this order are at still the early stage of development, but are better developed (and thicker) than the raw soils. The occurrence of A or O horizon 
which thickness often exceeds $10 \mathrm{~cm}$ is the most characteristic feature of these soils. According to PSC5, these A horizons are ochric epipedons, which cannot fulfill the criteria of other epipedons (e.g. mollic or umbric). Ochric horizon is no longer a diagnostic horizon in WRB, so the presence of weakly developed A horizons can be indicated by Ochric qualifier only. Two first soil types of this order (Table) are derived from hard rock, i.e. rankers (rankery) - from siliceous rocks (e.g. granite), and proper rendzinas (rędziny właściwe) - from carbonate rocks (e.g. limestone or dolomite). Continuous rock appears at the depth of tens of centimeters, but not deeper than $50 \mathrm{~cm}$, thus the soil may belong to Leptosols or other RSGs. Commonly present thick organic (litter) horizon (thickness $>10 \mathrm{~cm}$ ) may be expressed by Folic qualifier. Third soil type, pararendzinas (pararędziny), have unconsolidated parent materials rich in secondary carbonates. According WRB they can be put into Calcisols; however, their origin in Poland is mainly connected with erosion and truncation of the former soil surface. Other units (Arenosols, Fluvisols, and Regosols) are analogues with earlier discussed raw soils.

\section{Order 3: Brown earths (gleby brunatnoziemne)}

Soils of this order have cambic horizon distinguished using similar criteria in WRB and SGP5, with no other significant diagnostic horizons (only vertic and folic are allowed). Therefore, brown soils can be correlated with Cambisols in general. The only important difference is the texture requirement for cambic in PSC5, which allows loamy sand class and finer, while WRB requires sandy loam and finer only. Thus, the brown soils with sandy loam texture in Bw horizon have to be shifted to Brunic Arenosols (IUSS Working Group WRB 2015).

The order brown earths (gleby brunatnoziemne) comprises soils developed from various parent materials: alluvial deposits, glacial tills, or strongly weathered calcareous/siliceous bedrocks, which are classified in four separate soil types by PSC5 (Table). According to WRB they belong to one RSG, and the distinction is made by the following qualifiers: Dystric, Eutric, Fluvic, Dolomitic/Calcaric, respectively (Table). Some differences in assigning of Dystric or Eutric status have to be indicated: (i) the base saturation threshold is $60 \%$ in PSC while $50 \%$ in WRB, and (ii) the control section in PSC is a depth $25-75 \mathrm{~cm}$ below soil surface, while in WRB, the rules of Dytric/ Eutric naming are more flexible when using the prefixes (e.g. Amphidystric, Anoeutric etc.)

\section{Order 4: Rusty soils \\ (gleby rdzawoziemne)}

The profile of rusty soils has the sandy texture throughout, thus all these soils belong to Arenosols according to WRB (IUSS Working Group 2015). Endopedons sideric and rubic defined in PSC5 are not recognized in WRB as diagnostic horizons. Their presence is expressed by the use of Brunic or Rubic/ Chromic qualifiers, respectively. The only exceptions from the above mentioned classification are some ochrous soils (gleby ochrowe) with loamy rubic horizons. The loamy texture shifts this soil variant to Chromic/Rubic Cambisols.

\section{Order 4: Clay-illuvial soils (gleby płowoziemne)}

Clay-illuvial soils, often called soils lessives, most often have been correlated with Luvisols by Polish authors (e.g. Makuch 2012, Piotrowska and Długosz 2012, Kwiatkowska-Malina and Maciejewska 2013, Paluszek 2013) or, after the second edition of WRB, with Albeluvisols (Glina et al. 2013, Szymański et al. 2014). However, the third edition of WRB has re-evaluated the importance of albeluvic tonguing, which has spread the clay-illuvial soils to many different RSGs. The most important consequence for classification and cartography of soils with argic horizon in Poland is that the soil types of PSC5 cannot be simply correlated with RSGs of WRB.

Currently, only the non-gleyed proper clay-illuvial soils (gleby płowe typowe) can be simply correlated with Luvisols (Table). Both the proper clay-illuvial soils (gleby płowe typowe) and glossic clay-illuvial soils (gleby płowe zaciekowe) with an abrupt textural difference and periodic water stagnation over/in argic horizon are now correlated with Planosols (Kabała (Ed.) 2015, Musztyfaga and Kabała 2015). Furthermore, both the proper and glossic clay-illuvial soils with strong stagnic properties in the upper section of soil profile, but without abrupt textural difference may presently be correlated with Stagnosols (Kabała and Musztyfaga 2015). Only very few glossic clayilluvial soils belongs to Retisols (Świtoniak et al. 2014). This RSG has replaced former Albeluvisols, but strong stagnic properties and abrupt textural difference are in these soils excluded that makes this RSG rather a marginal one. Finally, some clay-illuvial soils characterized by very low base saturation have to be described as Alisols (Świtoniak 2008, Kabała and Musztyfaga 2015). Separate type of wet clayilluvial soils (gleby płowe podmokłe) are characterized by strong reductic conditions and gleyic properties 
starting near the surface, thus are a close counterpart of Luvic Gleysols.

\section{Order 6: Podzol soils (gleby bielicoziemne)}

All soils with spodic horizons, developed in course of podzolization, have been grouped in one order, closely related to Podzols of WRB (Table). Podzolic soils (gleby bielicowe) have humic horizon, while Podzols (bielice) are lacking A horizon (PSC 2011), which based on WRB may be distinguished by adding the Ochric qualifier to the first group.

\section{Order 7: Black soils (gleby czarnoziemne)}

Black soils are one of the most diverse and heterogeneous orders in the PSC5.

The definition of chernozems (czarnoziemy) in PSC5 is broader than its counterpart used in WRB as it partly includes the so-called "degraded chernozems". So, the soils which do not meet restrict criteria of organic matter content, colour, and structure as defined for chernic horizon (IUSS Working Group 2015), must be shifted to the Kastanozems (Fig. 2), even though it is not in line with original zonal concept of Kastanozems.

Black earths (czarne ziemie) are soils with mollic horizons and gleyic properties (Labaz and Kabała 2014). Some of them have calcic horizons just below the mollic, thus can be described as Gleyic Chernozems. Pedons without secondary carbonates, usually meet the requirements for Gleyic Phaeozems, whereas the soils strongly moist and gleyed at a very shallow depth may be correlated with Mollic Gleysols.

All next three types of soils with mollic horizons correspond to Phaeozems (Table). Depending on the origin and character of parent material these soil types are diversified at the second classification level. Chernozemic rendzinas (rędziny czarnoziemne) developed from carbonate rocks correlate well with Rendzic Phaeozems; humic alluvial soils (mady próchniczne) most often correlate with Fluvic Phaeozems, and humic colluvial soils (gleby deluwialne czarnoziemne) derived from slope deposits may be classified as Phaeozems with Colluvic supplementary qualifier (and various main qualifiers, e.g. Haplic, Luvic, Stagnic, Gleyic etc.). Cumulative

FIGURE 2. Correlation between the type Czarnoziemy in PSC5 and related RSGs in WRB:

1 - chernic horizon, 2 - mollic horizon, 3 - calcic horizon or protocalcic properties
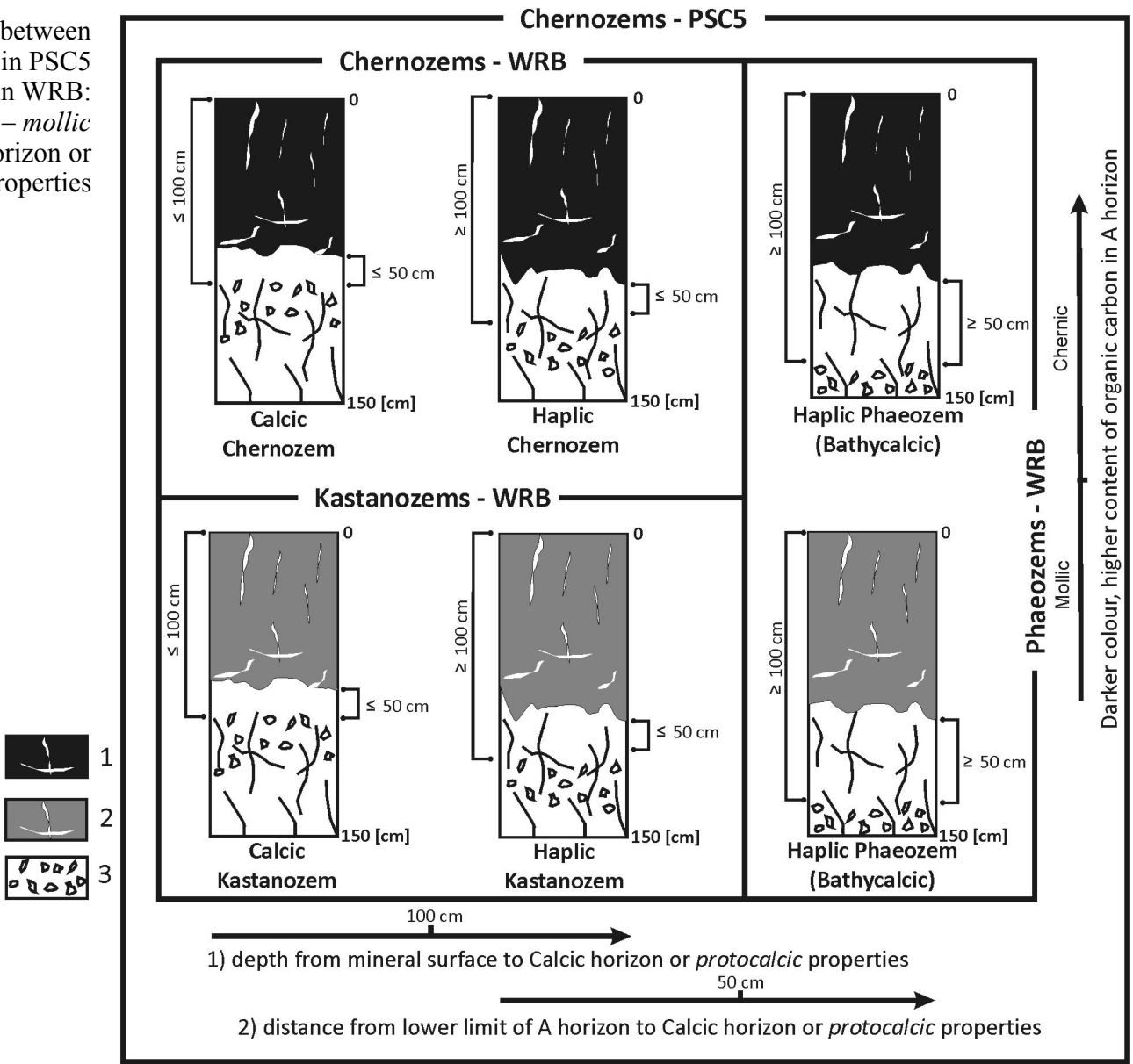
subtypes with humic horizon thicker than $60 \mathrm{~cm}$ allows to use the qualifier Pachic.

Postmurshic soils (gleby murszaste) have a dark, thick, acid, and sand-textured humus horizons characterized by lacking or weak organo-mineral complexes. These horizons have special definitions in PSC5, in relation to Polish tradition that distinguish several steps of peat material degradation and transformation of organic soil into mineral one after drainage and under intense land use (Labaz and Kabała 2016). WRB does not specify separate diagnostic horizons of this type, but the above mentioned layers fulfill criteria of umbric horizon. The common feature of postmurshic soils is high ground-water level. Therefore, they correlate with two RSG depending on the intensity of gleyic properties in the upper part of soil profile Umbric Gleysols or Gleyic Umbrisols. The soils are or were intensively cultivated, thus the umbric horizons exhibit also features of anthric properties which entitles to use Anthroumbric qualifier. A proposal of new specific qualifier for post-murshic horizons was also submitted to WRB (Labaz and Kabała 2016).

\section{Order 8: Gleysols (gleby glejoziemne)}

Soils saturated with groundwater for periods long enough to develop reduction conditions and gleyic properties at shallow depth represent Gleysols. However, the definition of gleysols in PSC5 is narrower than in WRB and does not include soils with diagnostic horizons such as mollic, umbric, argic, and spodic. However, histic horizon is allowed, giving the base for separation of two subtypes (Table).

\section{Order 9: Vertisols (vertisole)}

Soils developed from clayey materials, which have ability to seasonal shrinking and swelling, are described as Vertisols in both classification systems. WRB does not provide (in the list dedicated to this RSG) suitable qualifiers for first type in this order - acid vertisols (vertisole dystroficzne), but allows addition of Epidystric as supplementary qualifier, if applicable (Table). Second type, proper vertisols (vertisole eutroficzne), has carbonates starting $\leq 100 \mathrm{~cm}$ from the soil surface. Depending on the amount of secondary carbonates, the qualifiers Calcic or Protocalcic can be used. The most distinctive feature of last type humic vertisols (vertisole próchniczne), is dark and thick A horizon. In WRB it has to be emphasized by Pellic, which is intended for Vertisols only. It must be stated, that PSC5 does not allow mollic horizon presence in vertisols (soils with mollic/umbric horizon may be classified in the black soils order only).

$$
\begin{aligned}
& \text { Order 10: Organic soils } \\
& \text { (gleby organiczne) }
\end{aligned}
$$

Although the definition of organic soils in PSC5 and Histosols in WRB differ, these units are quite well correlated. Fibric, hemic and sapric peat soils (gleby torfowe fibrowe, hemowe i saprowe) are related to Fibric, Hemic, and Sapric Histosol, respectively. Limnic soils (where organic material was deposited as subaquatic sediment, e.g. gyttjas) correspond to Histosols with supplementary qualifier Limnic. Folic Histosols (gleby organiczne ściółkowe, folisole) are organic soils with thick folic horizon containing well-aerated litter directly on continuous rock (gleby organiczne ściółkowe płytkie, Folic Rockic Histosols) or in the fissures between stones/boulders (gleby organiczne ściółkowe typowe, Folic Mawic Histosols).

\section{Order 11: Anthropogenic soils (gleby antropogeniczne)}

The soils of this order were strongly transformed or created in course of intentional human activity. Two different groups of soils are assembled in this order, the soils which origins are related to agricultural activity, and soils which formation/transformation is related to construction and industrial/mining activities. The first group, called culturozems in PSC5 (gleby kulturoziemne) (Table), may be correlated with Anthrosols in WRB, as both they are distinguished based on similar criteria for diagnostic horizons such as hortic and plaggic. However, there are only some differences, as in the subtype rigosols (rigosole), that may not meet criteria of Anthrosols and, depending on the particular soil properties and morphology, may be scattered between many RSGs (Phaeozems, Arenosols, Regosols etc.). Much more problematic is the correlation of urbanozems and industrizems, which definition in PSC5 bases mainly on their localization and the fact of transformation in general, whereas the required content of artefacts is not clearly defined. However, it is believed, based on the existing reports (Charzyński et al. 2013 (Eds.)), that most of urbanozems and industrizems may be classified as Urbic or Spolic Technosols, respectively.

Salt-affected soils have presently a marginal position in PSC5 within the order of anthropogenic soils and require further improvement, as the salinization features occur in many "natural" soil taxa as a secondary characteristic (Hulisz 2016, Hulisz et al. 2010). According to WRB, these soils can be classified in 
different RSG's, mainly Gleysols and Technosols, using the Alkalic, Salic, and Sodic qualifiers.

\section{FINAL REMARKS}

This paper shows merely the most representative counterparts of soil units in PSC5 and WRB. Consequently, the listed above correlations should be used for general description of soil cover only, whereas individual pedons may represent another Reference Soil Group of WRB that was documented by many authors (e.g. Charzyński 2006, Mendyk et al. 2015). In the detailed studies based on individual soil description and analytical data all profiles should be conventionally classified using the key to the Reference Soil Groups (IUSS Working Group 2015).

\section{ACKNOWLEDGMENTS}

Dr hab. Piotr Hulisz is kindly acknowledged for suggestions on correlation of salt-affected soils. Publication of the paper was financed by the National Science Centre of Poland (research grant 2014/15/B/ ST10/04606).

\section{REFERENCES}

Brevik E.C., Calzolari C., Miller B.A., Pereira P., Kabała C., Baumgarten A., Jordán A., 2016. Soil mapping, classification, and pedologic modeling: History and future directions. Geoderma 264: $256-274$

Charzyński P., 2006. Testing WRB on Polish Soils. Association of Polish Adult Educators, Toruń: 1-110.

Charzyński P., Hulisz P., Bednarek R., 2013. (Eds.) Technogenic Soils of Poland. Polish Society of Soil Science, Toruń: $357 \mathrm{pp}$.

Dębska B., Banach-Szott M., Rosa E., Pakuła J., 2012. The effect of soil pollution by selected PAHs on the fractional composition of organic matter. Roczniki Gleboznawcze - Soil Science Annual 63(1): 13-17 (in Polish with English abstract).

Dokuchaev V.V., 1886. Glavnye momenty w istori otcenok zemel evropeyskoi Rossii s klassifikatiej russkich pochw. Otchyot Nizegorodskomu Gubernskomu zemstwu. Materialy k otcenke zemel Niznegorodskoy Guberni. Yestestvennoistoricheskaya chast. Wypusk I. Gl. V: 210-342; Yestestwenno-istoricheskaya klassifikatciya russkih pochw. Gl. VI: 342-391. Sankt Peterburg (in Russian).

FAO-ISSS-ISRIC, 1998. World Reference Base for Soil Resources. World Soil Resources Report 84. FAO, Rome: 155 pp.

Gajewski P., Kaczmarek Z., Owczarzak W., Mocek A., Glina B., 2015. Selected physical and water properties of soils located in the vicinity of proposed opencast lignite mine "Drzewce" (middle Poland). Soil Science Annual 66(2): 75-81.

Glina B., Jezierski P., Kabała C., 2013. Physical and water properties of Albeluvisols in the Silesian Lowland (SW Poland). Soil Science Annual 64(4): 123-129.

Glina B., Waroszewski J., Kabała C., 2014. Water retention of the loess-derived Luvisols with lamellic illuvial horizon in the Trzebnica Hills (SW Poland). Soil Science Annual 65(1): $18-24$.
Hulisz P., 2016. Coastal marsh soils in Poland: characteristics and problems of classification. Soil Science Annual 67(1): $37-44$.

Hulisz P., Charzyński P., Giani L., 2010. Application of the WRB classification to salt-affected soils in Poland and Germany. Polish Journal of Soil Science 43(1): 81-92.

Husnjak S., Rubinić V., Vrbek B., Špoljar A., 2010. Važnost, načela i pravila svjetske referentne osnovice za tlo (WRB) s primjerima korištenja u Hrvatskoj (The World Reference Base for Soil Resources (WRB) with the examples of its use in Croatia). Agronomski glasnik 63(5-6): 347-365.

IUSS Working Group WRB, 1998. World Reference Base for Soil Resources. World Soil Resources Reports 84, FAO, Rome: $186 \mathrm{pp}$.

IUSS Working Group WRB, 2006. World Reference Base for Soil Resources 2006. World Soil Resources Report 103, FAO, Rome: $186 \mathrm{pp}$.

IUSS Working Group WRB, 2015. World Reference Base for soil resources 2014. International soil classification system for naming soils and creating legends for soil maps. Update 2015. World Soil Resources Report 106. FAO, Rome: 188 pp.

Jankowski M., Rutkowska P., Bednarek R., 2014. Chronosequence of soils on inland dunes in Poland. [In:] M. Świtoniak, P. Charzyński (Eds.) Soil Sequences Atlas. Wydawnictwo naukowe UMK: 109-123.

Józefaciuk G., Czachor H., 2014. Impact of organic matter, iron oxides, alumina, silica and drying on mechanical and water stability of artificial soil aggregates. Assessment of new method to study water stability. Geoderma 221/222: 1-10.

Kabała C., 2014. Systematyka gleb Polski - stan aktualny i dalszy rozwój. (Classification of Polish Soils - current state and further development). Soil Science Annual 65(2): 91-98.

Kabała C., 2015. (Ed.) Soils of Lower Silesia origins, diversity, and protection. Polish Society of Soil Science, Polish Society of Humic Substances, Wrocław, Poland: 253 pp.

Kabała C., Bogacz A., Łabaz B., Szopka K., Waroszewski J., 2013. Różnorodność, dynamika i zagrożenia gleb (Diversity, dynamics and threats for soils). [In:] Knapik R., Raj A. (Eds.) Przyroda Karkonoskiego Parku Narodowego. Karkonoski Park Narodowy, Jelenia Góra: 91-126 (in Polish).

Kabała C., Musztyfaga E., 2015. Gleby płowe w systematyce gleb Polski i w klasyfikacjach międzynarodowych (Clay-illuvial soils in the Polish and international soil classifications). Soil Science Annual 66(4): 204-213.

Karklins A., 2002. A comparative study of the Latvian soil Classification with WRB. [In:] E. Micheli, F. O. Nachtergaele, R.J.A. Jones, L. Montanarella (Eds.), Soil Classification 2001. European Soil Bureau Research Report No. 7, EUR 20398 EN: 199-204.

Krasilnikov P.V., 2002. Soil terminology and correlation. Karelian Research Centre RAS, Petrozavodsk: 225 pp.

Krasilnikov P., Ibáńez Martí J-J., Arnold R. W., Shoba S., 2009. Handbook of soil terminology, correlation and classification. Earthscan, London-Sterling, VA: 325 pp.

Kwiatkowska-Malina J., Maciejewska A., 2013. Uptake of heavy metals by darnel multifloral (Lolium multiflorum Lam.) at diverse soil reaction and organic matter content. Soil Science Annual 64(1): 19-23.

Láng V., Fuchs M., Waltner I., Michéli E., 2013. Soil taxonomic distance, a tool for correlation: As exemplified by the Hungarian Brown Forest Soils and related WRB Reference Soil Groups. Geoderma 192(2013): 269-276. 
Łabaz B., Kabała C., 2014. Geneza, właściwości i klasyfikacja czarnych ziem w Polsce (Origin, properties, and classification of black earths in Poland). Soil Science Annual 65(2): 80-90.

Łabaz B., Kabała C., 2016. Human-induced development of mollic and umbric horizons in drained and farmed swampy alluvial soils. Catena 139: 117-126.

Makuch I., 2012. Forms of lead in profiles of differently use soil. Roczniki Gleboznawcze - Soil Science Annual 63(4): 41-45 (in Polish with English abstract).

Marcinek J., Komisarek J., Mocek A., Bednarek R., Skiba S., 2014. Sprostowania nieścisłości jakie znalazły się w artykule Stanisława Brożka pt. „Czy Systematyka gleb Polski, wydanie 5. dotyczy wszystkich gleb naszego kraju" opublikowanym w Rocznikach Gleboznawczych z. 63(3): 49-56. Soil Science Annual 65(1): 39-44.

Mendyk Ł., Świtoniak M., Bednarek R., Falkowski A., 2015. Genesis and classification of the soils developed from the sediments of the former Oleszek mill pond basin (the Chełmińskie Lakeland, N Poland). Soil Science Annual 66(1): 29-35.

Munteanu I., Florea N., 2002. Present-day status of Soil Classification in Romania. [In:] Micheli E., Nachtergaele F.O., Jones R.J.A., Montanarella L. (Eds.), Soil Classification 2001, EC, JRC, European Soil Bureau, Research Report 7, EUR 20398 EN: 55-62.

Musztyfaga E., Kabała C., 2015. Lithological discontinuity in Glossic Planosols (Albeluvisols) of Lower Silesia (SW Poland). Soil Science Annual 66(4): 180-190.

Nemeček J., Macků J., Vokoun J., Vavřiček D., Novák P., 2001. Taxonomický Klasifikační Systém Půd České Republiky. ČZU Praha - VÚMOP Praha, Praha (in Czech with English summary).

Palmieri F., Santos H., Gomes I., Lumbreras J., Aglio M., 2003. The Brazilian Soil Classification System. [In:] H. Eswaran, T. Rice, R. Ahrens, B.A. Stewart (Eds.) Soil Classification. A Global Desk Reference. CRC Press, Boca Raton London New York Washington D.C.: 127-146.

Paluszek J., 2013. Assessment of soil structure of Luvisols developed from loess classified in various complexes of agricultural suitability. Soil Science Annual 64(2): 41-48.

Pawlik Ł., Migoń P., Owczarek P., Kacprzak A., 2013. Surface processes and interactions with forest vegetation on a steep mudstone slope, Stołowe Mountains, SW Poland, Catena 109: 203-216.

Piotrowska A., Długosz J., 2012. Spatio-temporal variability of microbial biomass content and activities related to some physicochemical properties of Luvisols. Geoderma 173/174: 199-208.

Polish Soil Classification, 1989. Roczniki Gleboznawcze - Soil Science Annual 40(3/4): 150 pp.

Polish Soil Classification, 2011. Roczniki Gleboznawcze - Soil Science Annual 62(3): 193 pp.

Reintam E., Köster T., 2006. The role of chemical indicators to correlate some Estonian soils with WRB and Soil Taxonomy criteria. Geoderma 136: 199-209.

Secu C.V., Patriche C., Vasiliniuc I., 2008. Aspects regarding the correlation of the Romanian Soil Taxonomy System (2003) with WRB (2006), Soil Science 9(3-4): 56-62.
Shi X.Z., Yu D.S., Xu S.X., Warner E.D., Wang H.J., Sun W.X., Zhao Y.C., Gong Z.T., 2010. Cross-reference for relating Genetic Soil Classification of China with WRB at different scales. Geoderma 155: 344-350.

Soil Survey Staff, 1960. Soil Classification. A Comprehensive System. 7-th Approximation. U.S. Dept. of Agr. Soil Conservation Service. Washington D.C.

Soil Survey Staff, 2014. Keys to Soil Taxonomy, 12th ed. USDANatural Resources Conservation Service, Washington, DC.

Strzemski M., 1971. Myśli przewodnie systematyki gleb. IUNG, Puławy.

Szewczyk A., Kaniuczak J., Hajduk E., Knap R., 2015. Physical and chemical properties of selected soils from the surroundings of the Magura National Park (southern Poland). Soil Science Annual 66(1): 36-44.

Szymański W., Skiba M., Nikorych V.A., Kuligiewicz A., 2014. Nature and formation of interlayer fillings in clay minerals in Albeluvisols from the Carpathian Foothills, Poland. Geoderma 235/236: 396-409.

Świtoniak M., 2008. Classification of young glacial soils with vertical texture-contrast using WRB system. Agrochimija i Gruntoznawstwo 69: 96-101.

Świtoniak M., 2015. Issues relating to classification of colluvial soils in young morainic areas (Chełmno and Brodnica Lake District, northern Poland). Soil Science Annual 66(2): 57-66.

Świtoniak M., Charzyński P., 2014. (Eds.) Soil sequences atlas. Wydawnictwo Naukowe UMK, Toruń: 212 pp.

Świtoniak M., Charzyński P., Mendyk Ł., 2014. Forested areas within hummocky moraine plateaus of Poland (Brodnica Lake District). [In:] Soil sequences atlas. (Eds.) M. Świtoniak, P. Charzyński, Wydawnictwo Naukowe UMK, Toruń: 61-76.

Świtoniak M., Kabała C., Charzyński P., 2016. Proposal of recommended English equivalents for the soil taxa names of soil units in the Polish Soils Classification. Soil Science Annual (submitted).

Uzarowicz Ł., Skiba S., 2011. Technogenic soils developed on mine spoils containing iron sulphides: Mineral transformations as an indicator of pedogenesis. Geoderma 163(1-2): 95-108.

Waroszewski J., Kalinski K., Małkiewicz M., Mazurek R., Kozłowski G., Kabała C., 2013. Pleistocene-Holocene cover-beds on granite regolith as parent material for Podzols - An example from the Sudeten Mountains. Catena 104: 161-173.

Zadorova T., Penižek V., 2011. Problems in correlation of Czech National soil classification and World Reference Base 2006. Geoderma 167/168: 54-60.

Zagórski Z., Kisiel M., Kuśmierz A., 2015. Selected properties and systematic position of soils developed from red sandstones and clays of the lower Triassic Buntsandstein in the NW part of the Holy Cross Mountains (Poland). Soil Science Annual 66(3): 139-153.

Zgłobicki W., Baran-Zgłobicka B., Gawrysiak L., Telecka M., 2015. The impact of permanent gullies on present-day land use and agriculture in loess areas (E. Poland). Catena 126: $28-36$.

Received: April 28, 2016

Accepted: July 12, 2016 
TABLE. Correlation of soil units between Polish Soil Classification (2011) and WRB (IUSS Working Group WRB, 2015)

\begin{tabular}{|c|c|c|c|c|c|}
\hline Order & & Type & & Subtype & \\
\hline PSC 2011 & WRB 2015 & PSC 2011 & WRB 2015 & PSC 2011 & WRB 2015 \\
\hline \multirow[t]{6}{*}{$\begin{array}{l}\text { Gleby } \\
\text { inicjalne }\end{array}$} & \multirow{6}{*}{$\begin{array}{l}\text { Leptosols, } \\
\text { Regosols, } \\
\text { Arenosols, } \\
\text { Fluvisols }\end{array}$} & \multirow[t]{2}{*}{$\begin{array}{l}\text { Gleby inicjalne } \\
\text { skaliste }\end{array}$} & \multirow[t]{2}{*}{$\begin{array}{l}\text { Lithic } \\
\text { Leptos ols }\end{array}$} & $\begin{array}{l}\text { Gleby inicjalne skaliste } \\
\text { bezweglanowe (litosole) }\end{array}$ & Nudilithic/Lithic Leptosols \\
\hline & & & & $\begin{array}{l}\text { Rędziny inicjalne } \\
\text { skaliste }\end{array}$ & $\begin{array}{l}\text { Calcaric Nudilithic/Lithic } \\
\text { Leptosols }\end{array}$ \\
\hline & & \multirow[t]{2}{*}{$\begin{array}{l}\text { Gleby inicjalne } \\
\text { rumoszowe } \\
\text { (regosole) }\end{array}$} & \multirow[t]{2}{*}{$\begin{array}{l}\text { Hyperskeletic } \\
\text { Leptosols }\end{array}$} & $\begin{array}{l}\text { Gleby inicjalne } \\
\text { rumoszowe } \\
\text { bezwęglanowe }\end{array}$ & Hyperskeletic Leptosols \\
\hline & & & & Rędziny rumoszowe & $\begin{array}{l}\text { Calcaric/Dolomitic Hyperskeletic } \\
\text { Leptosols }\end{array}$ \\
\hline & & $\begin{array}{l}\text { Gleby inicjalne } \\
\text { erozyjne }\end{array}$ & Protic Regosols & - & Dystric/Eutric Protic Regosols \\
\hline & & $\begin{array}{l}\text { Gleby inicjalne } \\
\text { akumulacyjne }\end{array}$ & $\begin{array}{l}\text { Protic Arenosols; } \\
\text { Gleyic Fluvisols } \\
\text { (Protic); } \\
\text { Fluvic Gleysols } \\
\text { (Protic) }\end{array}$ & - & $\begin{array}{l}\text { Dystric Protic Arenosols; } \\
\text { Protic Gleyic Fluvisols (Arenic, } \\
\text { Protic); } \\
\text { Protic Fluvic Gleysols (Arenic, } \\
\text { Protic) }\end{array}$ \\
\hline \multirow{11}{*}{$\begin{array}{l}\text { Gleby } \\
\text { słabo } \\
\text { ukształto- } \\
\text { wane }\end{array}$} & \multirow{11}{*}{$\begin{array}{l}\text { Leptosols, } \\
\text { Regosols, } \\
\text { Arenosols, } \\
\text { Fluvisols, } \\
\text { Regosols, } \\
\text { Calcisols }\end{array}$} & \multirow[t]{4}{*}{ Rankery } & \multirow[t]{4}{*}{ Leptosols } & typowe & $\begin{array}{l}\text { Dystric/Eutric Skeletic Leptosols } \\
\text { (Ochric) }\end{array}$ \\
\hline & & & & butwinowe & Dystric Folic Leptosols (Ochric) \\
\hline & & & & $\mathrm{z}$ cechami bielicowania & $\begin{array}{l}\text { Dystric Leptosols } \\
\text { (Albic/Protospodic) }\end{array}$ \\
\hline & & & & $\mathrm{z}$ cechami brunatnienia & Cambic Leptosols (Ochric) \\
\hline & & \multirow[t]{2}{*}{ Rędziny właś ciwe } & \multirow[t]{2}{*}{ Calcaric Leptosols } & typowe & $\begin{array}{l}\text { Calcaric/Dolomitic Leptosols } \\
\text { (Ochric) }\end{array}$ \\
\hline & & & & butwinowe & $\begin{array}{l}\text { Calcaric/Dolomitic Folic } \\
\text { Leptosols (Ochric) }\end{array}$ \\
\hline & & \multirow[t]{2}{*}{ Pararędziny } & \multirow[t]{2}{*}{$\begin{array}{l}\text { Calcisols, Calcaric } \\
\text { Regosols }\end{array}$} & typowe & $\begin{array}{l}\text { Haplic Calcisols (Ochric); } \\
\text { Calcaric Regosols }\end{array}$ \\
\hline & & & & $\mathrm{z}$ cechami brunatnienia & $\begin{array}{l}\text { Haplic Calcisols (Ochric); } \\
\text { Calcaric Regosols }\end{array}$ \\
\hline & & Arenosole & Arenosols & - & $\begin{array}{l}\text { Dystric/Albic/Folic Arenosols } \\
\text { (Ochric) }\end{array}$ \\
\hline & & Mady właś ciwe & Fluvisols & - & $\begin{array}{l}\text { Dystric/Eutric/Gleyic Fluvisols } \\
\text { (Ochric) }\end{array}$ \\
\hline & & $\begin{array}{l}\text { Gleby słabo } \\
\text { ukształtowane } \\
\text { erozyjne }\end{array}$ & Regosols & - & $\begin{array}{l}\text { Dystric/Eutric/Skeletic Regosols } \\
\text { (Ochric) }\end{array}$ \\
\hline \multirow{16}{*}{$\begin{array}{l}\text { Gleby } \\
\text { brunatno- } \\
\text { ziemne }\end{array}$} & \multirow[t]{16}{*}{ Cambisols } & \multirow{6}{*}{$\begin{array}{l}\text { Gleby brunatne } \\
\text { eutroficzne }\end{array}$} & \multirow[t]{6}{*}{ Eutric Cambisols } & typowe & Endocalcaric Cambisols \\
\hline & & & & próchniczne & Endocalcaric Cambisols (Humic) \\
\hline & & & & wyługowane & Eutric Cambisols \\
\hline & & & & opadowo-glejowe & Eutric Stagnic Cambisols \\
\hline & & & & gruntowo-glejowe & Eutric Gleyic Cambisols \\
\hline & & & & $\mathrm{z}$ cechami vertic & Eutric Vertic Cambisols \\
\hline & & \multirow{6}{*}{$\begin{array}{l}\text { Gleby brunatne } \\
\text { dystroficzne }\end{array}$} & \multirow[t]{6}{*}{ Dystric Cambisols } & typowe & Dystric Cambisols \\
\hline & & & & próchniczne & Dystric Cambisols (Humic) \\
\hline & & & & $\mathrm{z}$ cechami bielicowania & Dystric Cambisols (Protospodic) \\
\hline & & & & opadowo-glejowe & Dystric Stagnic Cambisols \\
\hline & & & & gruntowo-glejowe & Dystric Gleyic Cambisols \\
\hline & & & & $\mathrm{z}$ cechami vertic & Dystric Vertic Cambisols \\
\hline & & \multirow[t]{2}{*}{ Mady brunatne } & \multirow[t]{2}{*}{ Fluvic Cambisols } & typowe & Fluvic Cambisols \\
\hline & & & & oglejone & Fluvic Gleyic Cambisols \\
\hline & & \multirow[t]{2}{*}{ Rędziny brunatne } & \multirow{2}{*}{$\begin{array}{l}\text { Dolomitic/Calcaric } \\
\text { Cambisols }\end{array}$} & typowe & Dolomitic/Calcaric Cambisols \\
\hline & & & & czerwonoziemne & $\begin{array}{l}\text { Dolomitic/Calcaric Chromic } \\
\text { Cambisols }\end{array}$ \\
\hline
\end{tabular}


Table continued

\begin{tabular}{|c|c|c|c|c|c|}
\hline Order & & Type & & Subtype & \\
\hline PSC 2011 & WRB 2015 & PSC 2011 & WRB 2015 & PSC 2011 & WRB 2015 \\
\hline \multirow{4}{*}{$\begin{array}{l}\text { Gleby } \\
\text { rdzawo- } \\
\text { ziemne }\end{array}$} & \multirow[t]{4}{*}{ Arenosols } & \multirow[t]{3}{*}{ Gleby rdzawe } & \multirow[t]{3}{*}{ Brunic Arenosols } & typowe & Dystric Brunic Arenosols \\
\hline & & & & $\mathrm{z}$ cechami bielicowania & Albic Brunic Arenosols \\
\hline & & & & gruntowo-glejowe & Brunic Gleyic Arenosols \\
\hline & & Gleby ochrowe & $\begin{array}{l}\text { Rubic/Chromic } \\
\text { Arenosols }\end{array}$ & typowe & Rubic/Chromic Arenosols \\
\hline \multirow{23}{*}{$\begin{array}{l}\text { Gleby } \\
\text { płowo- } \\
\text { ziemne }\end{array}$} & \multirow{23}{*}{$\begin{array}{l}\text { Luvisols, } \\
\text { Planosols, } \\
\text { Retisols, } \\
\text { Stagnosols, } \\
\text { Alisols }\end{array}$} & \multirow[t]{12}{*}{ Gleby płowe } & \multirow{12}{*}{$\begin{array}{l}\text { Mostly: Luvisols, } \\
\text { Planosols } \\
\text { (see: subtypes) }\end{array}$} & typowe & $\begin{array}{l}\text { Haplic/Albic Luvisols; } \\
\text { Albic Alisols }\end{array}$ \\
\hline & & & & spiaszczone & $\begin{array}{l}\text { Abruptic Luvisols (Epiarenic, } \\
\text { Endoloamic) - if there is no stagnic } \\
\text { features (seldom); Luvic Planosols } \\
\text { (Epiarenic, Endoloamic) - with } \\
\text { stagnic features (usually) }\end{array}$ \\
\hline & & & & spiaszczone oglejone & $\begin{array}{l}\text { Luvic Gleyic Planosols } \\
\text { (Epiarenic, Endoloamic) }\end{array}$ \\
\hline & & & & opadowo-glejowe & $\begin{array}{l}\text { Stagnic Luvisols; } \\
\text { Luvic Stagnosols }\end{array}$ \\
\hline & & & & gruntowo-glejowe & Gleyic Luvisols \\
\hline & & & & z poziomem agric & Albic Luvisols (Densic) \\
\hline & & & & próchniczne & Albic Luvisols (Aric, Humic) \\
\hline & & & & piaszczyste & Lamellic Luvisols (Arenic) \\
\hline & & & & $\mathrm{z}$ cechami brunatnienia & Albic Luvisols (Neocambic) \\
\hline & & & & $\mathrm{z}$ cechami bielicowania & Albic Alisols (Protospodic) \\
\hline & & & & $\mathrm{z}$ cechami glossic & Albic/Fragic Retisols \\
\hline & & & & z cechami vertic & Vertic Luvisols (Endoclayic) \\
\hline & & \multirow{9}{*}{$\begin{array}{l}\text { Gleby płowe } \\
\text { zaciekowe }\end{array}$} & \multirow{9}{*}{$\begin{array}{l}\text { Mostly: Retisols, } \\
\text { Planosols } \\
\text { (see: subtypes) }\end{array}$} & typowe & Albic/Glossic Retisols \\
\hline & & & & spiaszczone & $\begin{array}{l}\text { Albic Retisols (Abruptic, } \\
\text { Epiarenic, Endoloamic) - if no } \\
\text { Stagnic features (seldom); } \\
\text { Luvic Glossic Planosols } \\
\text { (Epiarenic, Endoloamic) - with } \\
\text { stagnic features (usually) }\end{array}$ \\
\hline & & & & opadowo-glejowe & $\begin{array}{l}\text { Stagnic Retisols - in case of } \\
\text { weak stagnic properties; } \\
\text { Luvic Glossic Stagnosols - in case } \\
\text { of strong stagnic properties }\end{array}$ \\
\hline & & & & gruntowo-glejowe & Gleyic Retisols \\
\hline & & & & z poziomem agric & Albic Retisols (Densic) \\
\hline & & & & próchniczne & Albic Retisols (Aric, Humic) \\
\hline & & & & $\mathrm{z}$ cechami brunatnienia & Albic Retisols (Neocambic) \\
\hline & & & & $\mathrm{z}$ cechami bielicowania & Albic Glossic Alisols (Protospodic) \\
\hline & & & & z cechami vertic & Vertic Retisols (Endogleyic) \\
\hline & & \multirow{2}{*}{$\begin{array}{l}\text { Gleby płowe } \\
\text { podmokłe }\end{array}$} & \multirow[t]{2}{*}{ Gleysols (Luvic) } & typowe & Dystric/Eutric Gleysols (Luvic) \\
\hline & & & & próchniczne & $\begin{array}{l}\text { Dystric/Eutric Gleysols } \\
\text { (Humic, Luvic) }\end{array}$ \\
\hline \multirow{6}{*}{$\begin{array}{l}\text { Gleby } \\
\text { bielico- } \\
\text { ziemne }\end{array}$} & \multirow[t]{6}{*}{ Podzols } & \multirow[t]{6}{*}{ Gleby bielicowe } & \multirow[t]{6}{*}{ Podzols } & typowe & Albic/Entic Podzols (Ochric) \\
\hline & & & & orsztynowe & Ortsteinic Podzols (Ochric) \\
\hline & & & & glejobielicowe typowe & Gleyic Albic Podzols (Ochric) \\
\hline & & & & $\begin{array}{l}\text { glejobielicowe } \\
\text { orsztynowe }\end{array}$ & $\begin{array}{l}\text { Gleyic Ortsteinic Podzols } \\
\text { (Ochric) }\end{array}$ \\
\hline & & & & $\begin{array}{l}\text { glejobielicowe } \\
\text { murszaste }\end{array}$ & Gleyic Podzols (Humic) \\
\hline & & & & glejobielicowe torfiaste & Gleyic Podzols (Humic) \\
\hline
\end{tabular}


Table continued

\begin{tabular}{|c|c|c|c|c|c|}
\hline Order & & Type & & Subtype & \\
\hline PSC 2011 & WRB 2015 & PSC 2011 & WRB 2015 & PSC 2011 & WRB 2015 \\
\hline \multirow{5}{*}{$\begin{array}{l}\text { Gleby } \\
\text { bielico- } \\
\text { ziemne }\end{array}$} & \multirow[t]{5}{*}{ Podzols } & \multirow[t]{5}{*}{ Bielice } & \multirow[t]{5}{*}{ Podzols } & typowe & Albic (Folic) Podzols \\
\hline & & & & orsztynowe & Albic Ortsteinic Podzols \\
\hline & & & & stagnobielice & Stagnic (Folic/Histic) Albic Podzols \\
\hline & & & & glejobielice typowe & Gleyic (Folic/Histic) Albic Podzols \\
\hline & & & & glejobielice orsztynowe & Gleyic Ortsteinic Albic Podzols \\
\hline \multirow[t]{23}{*}{$\begin{array}{l}\text { Gleby } \\
\text { czarno- } \\
\text { ziemne }\end{array}$} & \multirow{23}{*}{$\begin{array}{l}\text { Chernozems, } \\
\text { Phaeozems, } \\
\text { Kastanozems, } \\
\text { Umbris ols } \\
\text { Gleys ols }\end{array}$} & \multirow{5}{*}{ Czarnoziemy } & \multirow[t]{5}{*}{$\begin{array}{l}\text { Chernozems, } \\
\text { Kastanozems }\end{array}$} & typowe & $\begin{array}{l}\text { Haplic/Calcic Chernozems; } \\
\text { Haplic/Calcic Kastanozems; } \\
\text { Haplic Phaeozems (Bathycalcic) }\end{array}$ \\
\hline & & & & kumulacyjne & Haplic/Calcic Chernozems (Pachic) \\
\hline & & & & z poziomem cambic & $\begin{array}{l}\text { Haplic/Calcic Chemozems (Cambic); } \\
\text { Cambic Phaeozems (Bathycalcic) }\end{array}$ \\
\hline & & & & $\mathrm{z}$ poziomem argic & Luvic Chernozems \\
\hline & & & & opadowo-glejowe & Haplic/Calcic Chemozems (Stagnic) \\
\hline & & \multirow[t]{8}{*}{ Czarne ziemie } & \multirow[t]{8}{*}{$\begin{array}{l}\text { Gleyic Phaeozems, } \\
\text { Gleyic Chernozems }\end{array}$} & typowe & $\begin{array}{l}\text { Gleyic/Stagnic Phaeozems; } \\
\text { Gleyic/Stagnic Chernozems }\end{array}$ \\
\hline & & & & kumulacyjne & $\begin{array}{l}\text { Gleyic/Stagnic Phaeozems } \\
\text { (Pachic); Gleyic/Stagnic } \\
\text { Chernozems (Pachic) }\end{array}$ \\
\hline & & & & $\mathrm{z}$ poziomem cambic & Cambic Gleyic Phaeozems \\
\hline & & & & $\mathrm{z}$ poziomem argic & Luvic Gleyic/Stagnic Phaeozems \\
\hline & & & & $\mathrm{z}$ poziomem calcic & Gleyic/Stagnic Calcic Chernozems \\
\hline & & & & wyługowane & $\begin{array}{l}\text { Gleyic/Stagnic Phaeozems; } \\
\text { Gleyic/Stagnic Umbrisols }\end{array}$ \\
\hline & & & & glejowe & (Calcic) Mollic Gleysols \\
\hline & & & & murszaste & $\begin{array}{l}\text { Gleyic Umbrisols (Arenic, } \\
\text { Hyperhumic); Gleyic Phaeozems } \\
\text { (Hyperhumic) }\end{array}$ \\
\hline & & \multirow{3}{*}{$\begin{array}{l}\text { Rędziny } \\
\text { czarnoziemne }\end{array}$} & \multirow[t]{3}{*}{ Rendzic Phaeozems } & typowe & Rendzic Phaeozems \\
\hline & & & & $\mathrm{z}$ cechami brunatnienia & Cambic Rendzic Phaeozems \\
\hline & & & & opadowo-glejowe & Stagnic Rendzic Phaeozems \\
\hline & & \multirow[t]{2}{*}{ Mady czarnoziemne } & \multirow[t]{2}{*}{ Fluvic Phaeozems } & typowe & Fluvic Gleyic Phaeozems \\
\hline & & & & $\mathrm{z}$ cechami brunatnienia & Cambic Fluvic Phaeozems \\
\hline & & \multirow{2}{*}{$\begin{array}{l}\text { Gleby deluwialne } \\
\text { czarnoziemne }\end{array}$} & \multirow{2}{*}{$\begin{array}{l}\text { Phaeozems } \\
\text { (Colluvic) }\end{array}$} & typowe & Haplic Phaeozems (Colluvic) \\
\hline & & & & kumulacyjne & Haplic Phaeozems (Colluvic, Pachic) \\
\hline & & \multirow[t]{3}{*}{ Gleby murszaste } & \multirow[t]{3}{*}{$\begin{array}{l}\text { Umbric Gleysols; } \\
\text { Gleyic Umbrisols }\end{array}$} & typowe & $\begin{array}{l}\text { (Anthro)umbric Gleysols } \\
\text { (Arenic); intensively drained: } \\
\text { Gleyic Umbrisols (Arenic) }\end{array}$ \\
\hline & & & & żelazisto-murszaste & $\begin{array}{l}\text { (Anthro)umbric Gleysols (Arenic, } \\
\text { Ferric); intensively drained: } \\
\text { Gleyic Umbrisols (Arenic, Ferric) }\end{array}$ \\
\hline & & & & murszowate & $\begin{array}{l}\text { (Anthro)umbric Gleysols } \\
\text { (Humic/Hyperhumic) }\end{array}$ \\
\hline \multirow{5}{*}{$\begin{array}{l}\text { Gleby } \\
\text { glejoziemne }\end{array}$} & \multirow{5}{*}{ Gleysols } & \multirow[t]{5}{*}{ Gleby glejowe } & \multirow[t]{5}{*}{ Gleysols } & typowe & Dystric/Eutric Gleysols \\
\hline & & & & torfiasto-glejowe & Dystric/Eutric Gleysols (Humic) \\
\hline & & & & torfowo-glejowe & Histic Gleysols \\
\hline & & & & mułowo-glejowe & Fluvic Histic Gleysols \\
\hline & & & & murszowo-glejowe & Histic Gleysols (Murshic) \\
\hline
\end{tabular}


Table continued

\begin{tabular}{|c|c|c|c|c|c|}
\hline Order & & Type & & Subtype & \\
\hline PSC 2011 & WRB 2015 & PSC 2011 & WRB 2015 & PSC 2011 & WRB 2015 \\
\hline \multirow[t]{3}{*}{ Vertisole } & \multirow[t]{3}{*}{ Vertisols } & $\begin{array}{l}\text { Vertisole } \\
\text { dystroficzne }\end{array}$ & $\begin{array}{l}\text { Haplic Vertisols } \\
\text { (Epidystric) }\end{array}$ & - & - \\
\hline & & Vertisole eutroficzne & $\begin{array}{l}\text { Haplic Vertisols } \\
\text { (Protocalcic) } \\
\text { Calcic Vertisols } \\
\end{array}$ & - & - \\
\hline & & $\begin{array}{l}\text { Vertisole } \\
\text { próchniczne }\end{array}$ & $\begin{array}{l}\text { Pellic Vertisols } \\
\text { (Stagnic) }\end{array}$ & - & - \\
\hline \multirow{24}{*}{$\begin{array}{l}\text { Gleby } \\
\text { organiczne }\end{array}$} & \multirow[t]{24}{*}{ Histosols } & \multirow{3}{*}{$\begin{array}{l}\text { Gleby torfowe } \\
\text { fibrowe }\end{array}$} & \multirow[t]{3}{*}{ Fibric Histosols } & typowe & Fibric Histosols \\
\hline & & & & hemowo-fibrowe & Epifibric Endohemic Histosols \\
\hline & & & & limnowo-fibrowe & Fibric Histosols (Endolimnic) \\
\hline & & \multirow{6}{*}{$\begin{array}{l}\text { Gleby torfowe } \\
\text { hemowe }\end{array}$} & \multirow[t]{6}{*}{ Hemic Histosols } & typowe & Hemic Histosols \\
\hline & & & & saprowo-hemowe & Epihemic Endosapric Histosols \\
\hline & & & & fibrowo-hemowe & Epihemic Endofibric Histosols \\
\hline & & & & limnowo-hemowe & Hemic Histosols (Endolimnic) \\
\hline & & & & hemowe zamulone & Hemic Histosols (Mineralic) \\
\hline & & & & hemowe płytkie & $\begin{array}{l}\text { Hemic Histosols } \\
\text { (Mineralic/Limnic) }\end{array}$ \\
\hline & & \multirow{6}{*}{$\begin{array}{l}\text { Gleby torfowe } \\
\text { saprowe }\end{array}$} & \multirow[t]{6}{*}{ Sapric Histosols } & typowe & Sapric Histosols \\
\hline & & & & fibrowo-saprowe & Episapric Endofibric Histosols \\
\hline & & & & hemowo-saprowe & Episapric Endohemic Histosols \\
\hline & & & & limnowo-saprowe & Sapric Histosols (Endolimnic) \\
\hline & & & & saprowe zamulone & Sapric Histosols (Mineralic) \\
\hline & & & & saprowe płytkie & $\begin{array}{l}\text { Sapric Histosols } \\
\text { (Mineralic/Limnic) }\end{array}$ \\
\hline & & \multirow{2}{*}{$\begin{array}{l}\text { Gleby organiczne } \\
\text { ściółkowe }\end{array}$} & \multirow[t]{2}{*}{ Folic Histosols } & typowe & Mawic Folic Histosols \\
\hline & & & & $\begin{array}{l}\text { płytkie na skałach } \\
\text { litych }\end{array}$ & Rockic Folic Histosols \\
\hline & & \multirow{3}{*}{$\begin{array}{l}\text { Gleby organiczne } \\
\text { limnowe }\end{array}$} & \multirow[t]{3}{*}{ Histosols (Limnic) } & typowe & Drainic Histosols (Limnic) \\
\hline & & & & hemowo-limnowe & Hemic Histosols (Limnic) \\
\hline & & & & węglanowo-limnowe & $\begin{array}{l}\text { Drainic Histosols (Calcaric, } \\
\text { Limnic) }\end{array}$ \\
\hline & & \multirow{4}{*}{$\begin{array}{l}\text { Gleby organiczne } \\
\text { murszowe }\end{array}$} & \multirow[t]{4}{*}{ Murshic Histosols } & fibrowo-murszowe & Murshic Endofibric Histosols \\
\hline & & & & hemowo-murszowe & Murshic Endohemic Histosols \\
\hline & & & & saprowo-murszowe & Murshic Endosapric Histosols \\
\hline & & & & limnowo-murszowe & Murshic Histosols (Limnic) \\
\hline \multirow{4}{*}{$\begin{array}{l}\text { Gleby } \\
\text { antropo- } \\
\text { geniczne }\end{array}$} & \multirow{4}{*}{$\begin{array}{l}\text { Anthrosols, } \\
\text { Technosols }\end{array}$} & \multirow{4}{*}{$\begin{array}{l}\text { Gleby } \\
\text { kulturoziemne }\end{array}$} & \multirow[t]{4}{*}{ Anthrosols } & z poziomem plaggic & Plaggic Anthrosols \\
\hline & & & & $\begin{array}{l}\text { z poziomem hortic } \\
\text { (hortisole) }\end{array}$ & Hortic Anthrosols \\
\hline & & & & $\mathrm{z}$ poziomem anthric & $\begin{array}{l}\text { Hortic Anthrosols; Haplic } \\
\text { Phaeozems (Anthric); } \\
\text { Haplic/Mollic Umbrisols (Anthric) }\end{array}$ \\
\hline & & & & regulówkowe (rigosole) & $\begin{array}{l}\text { many soil units with plough layer } \\
\text { thickness }>50 \mathrm{~cm} \text {, e.g. Fluvic } \\
\text { Phaeozems (Pachic), Gleyic } \\
\text { Umbrisols (Pachic); Haplic } \\
\text { Luvisols (Anoaric) }\end{array}$ \\
\hline
\end{tabular}


Table continued

\begin{tabular}{|c|c|c|c|c|c|}
\hline Order & & Type & & Subtype & \\
\hline PSC 2011 & WRB 2015 & PSC 2011 & WRB 2015 & PSC 2011 & WRB 2015 \\
\hline \multirow{8}{*}{$\begin{array}{l}\text { Gleby } \\
\text { antropo- } \\
\text { geniczne }\end{array}$} & \multirow[t]{8}{*}{$\begin{array}{l}\text { Antrosols, } \\
\text { Technosols }\end{array}$} & \multirow[t]{3}{*}{$\begin{array}{l}\text { Gleby } \\
\text { industrioziemne }\end{array}$} & $\begin{array}{l}\text { Technosols, } \\
\text { Regosols }\end{array}$ & inicjalne & $\begin{array}{l}\text { Spolic Technosols, Relocatic } \\
\text { Regosols }\end{array}$ \\
\hline & & & & próchniczne & Spolic Technosols (Humic/Ochric) \\
\hline & & & & $\begin{array}{l}\text { przekształcone } \\
\text { chemicznie }\end{array}$ & $\begin{array}{l}\text { various soil units (eg. Technosols, } \\
\text { Regosols, Luvisols) with Toxic } \\
\text { qualifier }\end{array}$ \\
\hline & & \multirow[t]{4}{*}{ Gleby urbiziemne } & \multirow[t]{4}{*}{ Urbic Technosols } & inicjalne & $\begin{array}{l}\text { Urbic Technosols, Relocatic } \\
\text { Regosols }\end{array}$ \\
\hline & & & & próchniczne & Urbic Technosols (Humic/Ochric) \\
\hline & & & & $\begin{array}{l}\text { przekształcone } \\
\text { chemicznie }\end{array}$ & $\begin{array}{l}\text { various soil units (e.g. Technosols, } \\
\text { Regosols, Luvisols) with Toxic } \\
\text { qualifier }\end{array}$ \\
\hline & & & & $\begin{array}{l}\text { uszczelnione lub } \\
\text { przykryte (ekranosole) }\end{array}$ & Ekranic Technosols \\
\hline & & $\begin{array}{l}\text { Gleby słone } \\
\text { i zasolone }\end{array}$ & $\begin{array}{l}\text { Gleysols, } \\
\text { Technosols }\end{array}$ & - & $\begin{array}{l}\text { various soil units (e.g. Gleysols, } \\
\text { Technosols) with Alkalic, Salic or } \\
\text { Sodic qualifiers }\end{array}$ \\
\hline
\end{tabular}

\section{Korelacja między Systematyką gleb Polski (2011) a Światową Bazą Referencyjną Zasobów Glebowych WRB (2015)}

Streszczenie: Ostatnie wydanie Systematyki gleb Polski zawiera tabelę korelacyjną z World Reference Base for Soil Resources (WRB), która jest najczęściej wykorzystywaną klasyfikacją międzynarodową przez polskich gleboznawców. Jednakże, najnowsze wydanie WRB (IUSS Working Group WRB 2015) wprowadziło wiele istotnych zmian, co spowodowało zdezaktualizowanie się wielu wcześniejszych korelacji. Niniejsza publikacja prezentuje najbliższe odpowiedniki rzędów, typów i podtypów gleb wyróżnionych w piatym wydaniu Systematyki gleb Polski oraz grup referencyjnych WRB (IUSS Working Group WRB 2015). Przedstawione propozycje mogą znaleźć zastosowanie w ogólnej korelacji jednostek glebowych na mapach i w bazach danych, a także mogą być wykorzystywane przez polskich gleboznawców przy ustalaniu indywidualnych odpowiedników dla badanych gleb. Ponadto, zaproponowana tabela korelacyjna ułatwi odbiór Systematyki gleb Polski w międzynarodowym środowisku gleboznawczym.

Stowa kluczowe: Systematyka gleb Polski, WRB, odpowiedniki, referencyjne grupy gleb, typy gleb 